\title{
Splątane światy literatury i filmu
}

ABSTRACT. Krajewska Anna, Splątane światy literatury i filmu [The Entangled Worlds of Literature and Film]. „Przestrzenie Teorii” 32. Poznań 2019, Adam Mickiewicz University Press, pp. 7-12. ISSN 1644-6763. DOI 10.14746/pt.2019.32.0.

In view of the relations between literature and film, the article contains suggestions for ways to use performative approaches, which preclude concepts of adaptation, in favour of processes defining actions involving the entanglement of the arts.

KEYWORDS: film, literature, dramaturgy, entangled arts, performative humanities

Istotą tego numeru jest... czekanie i retardacja. Odwlekamy odpowiedzi, przesuwamy akcenty, dodajemy znaczenia, zadajemy pytania, na które istnieją różne odpowiedzi (lub może nie ma ich wcale...). Kiedy Profesor Wojciech Otto, dyrektor Instytutu Filmu, Mediów i Sztuk Audiowizualnych UAM zaproponował mi wydanie numeru poświęconego związkom filmu i literatury, przemknęły mi błyskawicznie przez głowę dwie myśli - pierwsza: tylko nie adaptacja! I druga: z czym chcemy się zmierzyć? Zgodziłam się, by podjąc taki temat, widząc w nim szansę na pokazanie, czym staje się dziś literaturoznawstwo wchodzace coraz aktywniej w sferę medioznawstwa. A zatem, czy chodzi rzeczywiście tylko o relacje film/literatura (ujmowane binarnie, widziane często jeszcze w perspektywie semiotyki jako przekład intersemiotyczny), czy jednak o coś więcej, o próbę określenia charakteru zmiany naszego myślenia dotyczącego procesów określających nowe sposoby badania sztuki (już nie jako zbioru artefaktów, ale ujmowanych w perspektywie zdarzeń jako dramaturgia sztuki). Moim zdaniem widać dziś wyraźnie efekt odejścia od utopijnych marzeń o wielkiej teorii na rzecz pokazywania, „uchwytywania”, realnej pracy pola, w którym wciąz zachodza procesy wytwarzania wiedzy rozumianej nie jako przyrost faktów, ale jako projektowanie serii działań.

Gdy mówimy o literaturze i filmie (albo, dodajmy, o literaturze i teatrze), szczególnie często wraca problem adaptacji. Spory nie ustaja, i choć trwaja od wielu lat, temat wydaje się jednak wciąż goracy, ale i... męczący. Wobec istnienia wielu prac na ten temat, posłużmy się wyłącznie dla potrzeb tego wstępu, zaprezentowanym przez Alicję Helman, z wykorzystaniem bogatej literatury polskiej i światowej, krótkim przeglądem stanowisk dotyczących adaptacji. Autorka wcześniej sama od dawna podważała sens adaptacji, pisząc między innymi, że adaptacja rozumiana jako „dający się wyznaczyć 
i zdefiniować na całym obszarze kina i literatury model związków tych dwu sztuk, na przykład jako przekład intersemiotyczny, nie istnieje. [...] Film literatury nie adaptuje, on z niej korzysta" ${ }^{1}$. W tekście Odwieczny temat: adaptacje wylicza i omawia przykładowo teorię przekładu, a zwłaszcza przekładu intersemiotycznego, ekwiwalencji, transferu, pokazuje ujęcia taksonomiczne (określające długą listę możliwych zapożyczeń, nawiązań, transformacji i krzyżowań, określających tzw. problem „wierności” wobec oryginału), podsumowuje, dokonywane zwłaszcza w nowszych opracowaniach, próby zastąpienia pojęcia adaptacji innymi terminami, jak np. imitacja, re-kreacja, bądź omawia triady: przywłaszczenie, przepisanie, hybrydyczność czy transkrypcję, komentarz, analogię, a także transmutację, transfigurację, kanibalizację, a nawet odwołania do Bachtinowskiej dialogiczności czy Genetowskiej transtekstualności lub całkiem nowego zjawiska adaptacji fanowskich itd. itp. Na koniec swego przeglądu Alicja Helman zwraca uwage na stanowisko Henry'ego Jenkinsa, który inaczej stawia problem, pisząc nie tyle o adaptacji, ile o konwergencji mediów i o nieustannym przeobrażaniu się sfery transmedialnej, otwierając tym samym nowe sposoby myślenia nie tylko w ramach medioznawstwa ${ }^{2}$.

Problem wydaje się więc szerszy; dotyczy konieczności przemyślenia na nowo naszego widzenia sposobów istnienia sztuki. Problem nie zniknie, gdy pisanie o relacjach między sztukami wciąż będziemy określać w kategoriach binarnych, próbować definiować ich odrębność, starać się oddzielać je od siebie, gdy powtórzymy kolejny raz: literatura to sztuka słowa, film to ruchome obrazy, malarstwo to barwne plamy, muzyka to organizacja dźwięku itd. itp. Problem nie zniknie nawet wtedy, gdy antybinarność będziemy rozumieć jako przekraczanie granic (które jednak może sprowadzać się tylko do zainteresowania obszarami „pomiędzy”, albo stosowaniem dialektyki prowadzącej do syntezy, czy też wprowadzaniem pojęć związanych z hybrydycznościa, stopem, amalgamatem itp.). Dopóki nie przemyślimy na nowo nie tyle pojęcia samej sztuki, ile sposobów naszego do niej podejścia, dopóty nie uda nam się wybrnać z impasu, który rodzi pozorną konieczność stosowania nadal kategorii adaptacji czy przekładu intersemiotycznego.

Proponuję zatem odejście od chęci czy potrzeby definiowania pojedynczych pojęć (zwłaszcza w dobie ich wędrówki, przemieszczania sensów czy zmiany charakteru z opisowego na operacyjne) na rzecz przyjrzenia się sposobom naszego postrzegania zjawisk kultury, nauki, sztuki.

${ }^{1}$ A. Helman, Modele adaptacji filmowej. Próba wprowadzenia w problematykę, „Kino” 1979, nr 6, s. 28-30.

${ }^{2}$ A. Helman, Odwieczny temat: adaptacje, <http://ekrany.hekko24.pl/images/teksty/16_ helman_adaptacje.pdf> [dostęp: 2.03.2020]. 
Sztukę widziałabym jako pole działań, które podejmujemy każdorazowo inaczej i niepowtarzalnie po to, by uciekać od terminologicznych i definicyjnych przyszpileń. Dzieła nie istnieją jako stabilne, statyczne, niezmienne artefakty - każdy z nas uruchamia zawsze proces tworzenia, który - jako zmienny - równoznaczny jest raz z działaniem artystycznym (artysty, fana, uczestnika zdarzeń...), a innym razem ze sposobem odkrywania wiedzy (uczonego w laboratorium, rozumianym, jak chciał Bruno Latour, jako łącznik między światem wnętrza zamkniętego pomieszczenia z przestrzenia zewnętrzną procesów i zdarzeń $\left.{ }^{3} . ..\right)$. Ten akt tworzenia, nieopozycyjny wobec procesu odbioru, można by nazwać, wykorzystując określenie Jonathana Crary'ego, które zastosował w opisie percepcji obrazów, zjawiskiem „zawieszenia percepcji”". Jeśli przyjmiemy, że nie ma niczego przedustanowionego, a sztuka nie jest jedynie odwzorowaniem istniejącego poza nią świata, powiedzieć można, że akty zawieszania percepcji mają moc performatywna, powołując do życia to, co starają się opisać.

Problem adaptacji może pojawiać się wtedy, gdy o sztukach myślimy w kategoriach binarnych; oto literatura, oto film, oto teatr itp. Problem adaptacji znika, jeśli zaczynamy o sztuce myśleć poza wszelkimi opozycjami, jak dzieje się to np. w dyskursach synestezyjnych czy odbiorach anamorficznych, bez stosowania podziałów, np. na sztuki słowa, sztuki wykonawcze, sztuki wizualne.

W proponowanym ujęciu każda sztuka jest performatywna (znika wtedy potrzeba stosowania odrębnej kategorii sztuk performatywnych), ponieważ przyjęte tu założenia sprawiaja, że performatywność staje się cechą podstawową dla całego obszaru zjawisk i procesów, które sztukę kształtuja.

Sztuka istnieje in performance, w rozwoju, procesie, płynności, ruchu, akcji. Jeśli, na wzór refleksji o języku, chcemy powiedzieć, że sztuka performatywnie kształtuje świat, to w domyśle musimy przyjąć, że sztuka kształtuje świat. Sztuka performatywnie kształtuje świat, znaczy zatem tyle, że wytwarza dyskurs, którego wcześniej w dziele nie było. Opisując rzeczywistość, równocześnie ją stwarza. Mówiąc językiem Paula de Mana, performatywy jako retoryczne operacje są pewnymi aktami języka, które podkopując jego roszczenia, by reprezentować to, co uprzednio już istnieje, równocześnie organizuja świat ${ }^{5}$. Historię aporii performatywu i konstatywu wykłada między innymi Jonathan Culler w swej książce poświęconej literaturze w teorii ${ }^{6}$. Ciekawe,

${ }^{3}$ B. Latour, Dajcie mi laboratorium a porusze świat, przekł. K. Abriszewski, Ł. Afeltowicz, „Teksty Drugie” 2009, nr 1-2.

${ }^{4}$ J. Crary, Zawieszenia percepcji. Uwaga, spektakl i kultura nowoczesna, przekł. Ł. Zaremba, I. Kurz, redakcja naukowa i posłowie I. Kurz, Warszawa 2009.

${ }^{5}$ P. de Man, Ideologia estetyczna, przeł. A. Przybysławski, wstęp A. Warminski, Gdańsk 2000.

${ }^{6}$ J. Culler, Performatyw, [w:] tegoż, Literatura w teorii, przeł. M. Maryl, Kraków 2013.

9 Splątane światy literatury i filmu 
że ilustrując procesy performatywne, wielu autorów wykorzystuje matryce dramaturgiczne. Gilles Deleuze pisze o przechodzeniu „teatru przedstawienia w teatr powtórzenia"7, a Jacques Derrida buduje podwójną scenę (la double séance), odwołując się do mima grającego scenę zabójstwa swojej żony...

Jeśli przyjmiemy koncepcję literatury jako performatywu, jako uruchomienie aktu, którym powołuje do życia to, co nazywa, przyjmiemy to rozumowanie $\mathrm{z}$ łatwościa, ponieważ w przypadku literatury mamy do czynienia z wypowiedziami językowymi. Ale literatura, to już nie tylko słowa, ale i obrazy (myślę nie tyle o wizualności, ile o animacji, czy o bliskiej performansowi liberaturze, komiksie itp.). Czy zatem literatura może być czymś innym niż słowem? Czy literatura może być filmem? Czy literatura może być teatrem? Czy literatura jest osobnym medium, czy może raczej realizować się poprzez różne media (a złudzenie, że mamy do czynienia ze stabilnym dziełem wyrażonym w słowach dał nam jedynie druk)?

Jeśli przyjmiemy także koncepcję filmu jako sztuki performatywnej, możemy z pewnością powtórzyć to samo, czyli uznać fakt, że w filmie zachodzą podobne zjawiska jak w literaturze nie tylko dlatego, że występują w nim słowa, ale dlatego, że film także powołuje performatywnie do istnienia świat, który nazywa. Nieważne zatem, czy weźmie z literatury jakieś odwołanie, cytat, tytuł, wątek fabularny czy w inny sposób do niej nawiąże, zawsze wytworzy w tym momencie własny świat, który nie będzie nigdy odwzorowaniem literatury, ale jej wykreowaniem, wytworzeniem od początku. Hamlet filmowy z Richardem Burtonem w roli głównej wyświetlany (i równocześnie wymazywany) na teatralnej scenie Wooster Group, filmowy Makbet, czyli Tron we krwi Akiry Kurosawy nazywaja światy, które nazywając, równocześnie kreuja.

Performatyka dała moim zdaniem podstawę mówienia o sztuce w perspektywie antybinarnej jako o zjawisku ruchomym. Konsekwencją takiego myślenia byłoby poszukiwanie innych zasad mówienia o korelacji sztuk (już nie tyle w kategoriach korespondencji, syntezy czy transmedialności, ile może w pojęciach odwołujących się do ruchu: notacji tanecznych, aktów splątywania, uprawiania dramatografii itp.). Z kategorii poetyki opisowej przeszliśmy do pojęć estetyki performatywnej. Przeszliśmy wyraźnie zmiany myślenia; z kategorii „,chwytu”, „tropu”, „środków poetyckich”, „tekstu”, „delimitacji”, „ramy” zmierzamy ku pojęciom określającym niestabilność, niepewność, wahanie, brak, nieobecność, wymazywanie, ruch, niestabilnym, zmiennym. Jakże przydaja się teraz kategorie filmowe: nie kadr, ale ruchy kamer i operowanie światłem (najazd, zoom, budowanie zmiennym światłem i cieniem, smużenie, wymazywanie, znikanie itp.). A więc nie sam gotowy

${ }^{7}$ G. Deleuze, Różnica i powtórzenie, przeł. B. Banasiak, K. Matuszewski, Warszawa 1997, s. 39. 
efekt montażu, ale pokazywanie aktu montowania lub dekonstruowania. Nie cechy samej materii, ale sposoby jej wykorzystania (niczym zaskakujące doniesienie o tym, że np. pszczoła zrobiła gniazdo z plastiku), albo jej powstawania (ukorawianie, przetwarzanie, wplątywanie materii). Nowa estetyka to już nie zgniatanie, kompresja, recycling, już nie kolaż, ambalaż, assamblaż, już nie secesyjne łączenie, ale splątywanie jako akt udzielania sobie cech, przejmowania sposobów postrzegania świata, z akcentem na wymianę tożsamości, jak skomplikowana rola maski w teatrze nō, jak performatyka ciała w notacji butō). Gdyby dało się powiedzieć skrótowo: przeszliśmy w naszym pisaniu i myśleniu o sztuce z etapu układania teorii do praktykowania teorii (jako sztuki), od teorii jako sztuki oglądania (teoria jako teatr) do teorii jako sztuki performowania (teoria jako performans). Czerpiąc z bliższego mi obszaru teatru, powiedziałabym, że przeszliśmy z teorii dramatu do dramaturgii sztuki. Dramatografia dotyczy jednak także filmu. W kategoriach filmowych coraz to częściej widzimy literaturę, a film w kategoriach literatury. Nie dzieje się tak jednak poprzez przekładanie, ani nawet iterowalność, ale o czym pisałam wielokrotnie - poprzez akty splatywania (nazwane tak na wzór terminów z fizyki kwantowej). Audiodeskrypcja filmowa uświadomiła nam najwyraźniej, jak splątać obraz ze słowem (nie chodzi tu, by używać, za Horacym, maksymy „poezja jak obraz”, ale by sprawiać, że słowo staje się obrazem). W audiodeskrypcji słowo i obraz udzielają się sobie, splątuja. Film i literatura idą razem. Widzieć słowa oznacza tu synestezję, a nie ekfrazę. Dlatego, jak się wydaje, doskonała audiodeskrypcja jest sztuka, a nie techniką opisu. Audiodeskrypcja jest sztuką performatywna, opisując świat, stwarza go, dając nadzieję na widzenie niewidzianego.

Proponowane tu widzenie literatury i filmu w kategorii splatania, rodzi też pytania o status takich sztuk, jak np. utwory Samuela Becketta. Czym jest Film? Czym sztuka telewizyjna Kwadrat? Czy sa obrazami? Scenariuszami filmowymi? Notacjami muzycznymi? Czy notacjami tanecznymi? A może ilustracjami stwierdzeń filozoficznych?

Nawiązując do umieszczonego w początkowych uwagach do Filmu Becketta formuły George'a Berkeleya Esse est percipi (Być, znaczy być postrzeganym), Dariusz Pawelec (reżyser, operator kamery, scenarzysta) pisze, że poza podstawowym pytaniem ontologicznym wiążącym byt z postrzeganiem „uderzające jest jednak, jak cytat z Berkeleya może oddać metaforycznie istotę pracy operatora filmowego", i zaraz dodaje (co mogłoby być przesłaniem naszego numeru): „Choć pewnie trafniejsza byłaby parafraza tego słynnego cytatu "być to znaczy być sfilmowanym»".

${ }^{8}$ D. Pawelec, <http://bip.filmschool.lodz.pl/userfiles/4_autoreferat_po_polsku2.pdf> [dostęp: 2.03.2020]. 


\section{BIBLIOGRAFIA}

Crary J., Zawieszenia percepcji. Uwaga, spektakl i kultura nowoczesna, przekł. Ł. Zaremba, I. Kurz, redakcja naukowa i posłowie I. Kurz, Warszawa 2009.

Culler J., Performatyw, [w:] tegoż, Literatura w teorii, przeł. M. Maryl, Kraków 2013.

Deleuze G., Różnica i powtórzenie, przeł. B. Banasiak, K. Matuszewski, Warszawa 1997.

Helman A., Modele adaptacji filmowej. Próba wprowadzenia w problematykę, „Kino” 1979, nr 6, s. 28-30.

Helman A., Odwieczny temat: adaptacje, <http://ekrany.hekko24.pl/images/teksty/16_ helman_adaptacje.pdf $>$ [dostęp: 2.03.2020].

Latour B., Dajcie mi laboratorium a poruszę świat, przekł. K. Abriszewski, Ł. Afeltowicz, „Teksty Drugie” 2009, nr 1-2.

Man P. de, Ideologia estetyczna, przeł. A. Przybysławski, wstęp A. Warminski, Gdańsk 2000.

Pawelec D., <http://bip.filmschool.lodz.pl/userfiles/4_autoreferat_po_polsku2.pdf> [dostęp: 2.03.2020]. 


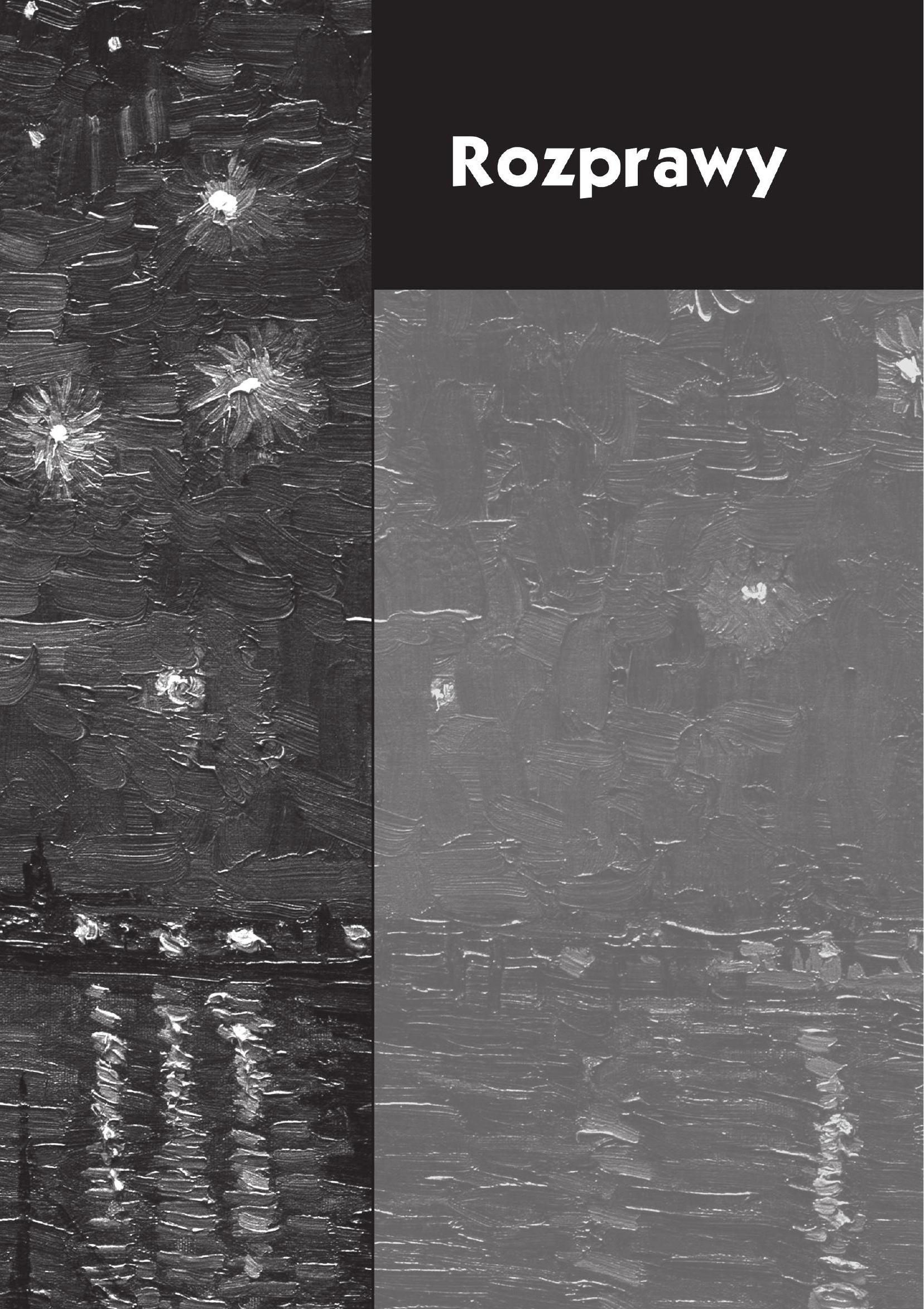


